\title{
EXPERIMETAL MEASUREMENT OF SOIL-PRESTRESSED FOUNDATION INTERACTION
}

\author{
Radim Cajka ${ }^{1}$, Petr Mynarcik² and Jana labudkova ${ }^{3}$ \\ ${ }^{1}$ Department of Structures, Faculty of Civil Engineering, VSB-Technical University Ostrava, Ludvika \\ Podeste 1875/17, 708 33, Ostrava - Poruba, Czech Republic \\ ${ }^{2}$ Department of Structures, Faculty of Civil Engineering, VSB-Technical University Ostrava, Ludvika \\ Podeste 1875/17, 708 33, Ostrava - Poruba, Czech Republic \\ ${ }^{3}$ Department of Structures, Faculty of Civil Engineering, VSB-Technical University Ostrava, Ludvika \\ Podeste 1875/17, 708 33, Ostrava - Poruba, Czech Republic
}

\begin{abstract}
Several experimental measurements of reinforced concrete slab - subsoil interaction are compared with numerical analysis of shallow foundation by means of FEM. At the Faculty of Civil Engineering VSB - Technical University of Ostrava testing device was constructed so that the phenomena of soil - foundation interaction could be experimentally investigated and compared with numerical models. The experimental model was designed as a cutout of prestressed foundation slab-on-ground and the static load test was conceived as a simulation of local loading of a square shape column. During the static load test, measurements focused on observation of horizontal deformations, tension inside the slab and on the contact surface between foundation structure and subsoil. The described static load test was part of a series of experiments realized at the Faculty of Civil Engineering, VSB -Technical university of Ostrava.
\end{abstract}

Keywords: Foundation structure, experimental measurement, soil - structure interaction, interaction models, contact stress, FEM calculation.

\section{INTRODUCTION}

This article presents experimental static load test of post-tensioned concrete foundation model. This test was part of a series of experiments focused on problematic of interaction between concrete structures and subsoil and was realized at the Faculty of Civil Engineering, VSB - Technical university of Ostrava.

Subsoil-structure interaction problematic is international research theme and many research teams around the world produce research activity on this scope [1]-[6]. Interaction between concrete structure and subsoil is one of the main research directions at the Faculty of Civil Engineering, VSB - Technical university of Ostrava [7]-[12].

Actually, research is focused on post-tensioned concrete foundation slabs and industrial floors. For experimental static load test was concreted model of post-tensioned foundation slab and static load test was conceived as a simulation of loading by square shape column. The experiment served to a better understanding and possible improvement of these technologies from the perspective of subsoil interaction. This problematic is actual for areas with earthquake activity, undermining areas and areas with difficult foundation behavior [24], [25].
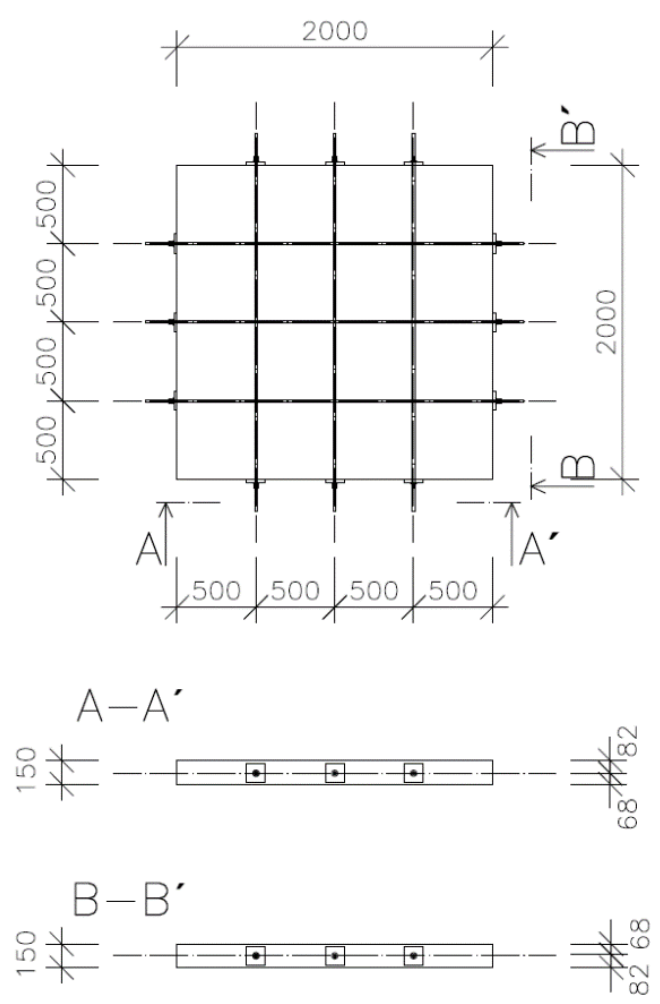

Fig. 1 The schematic plan of experimental model dimensions and prestressing threadbars positions 


\section{DESTCRIPTION OF THE PRESTRESSED CONCRETE FLOOR MODEL}

The experimental model was designed as a cutout of prestressed concrete foundation slab. Schematic plan of experimental model is displayed on Fig. 1. The basic dimensions of experimental model were $2000 \times 2000 \times 150 \mathrm{~mm}$. The concrete type C35/45 XF1 was used for concreting. The experimental model was post tensioned by six fully threaded prestressing threadbars - displayed on Fig. 2.

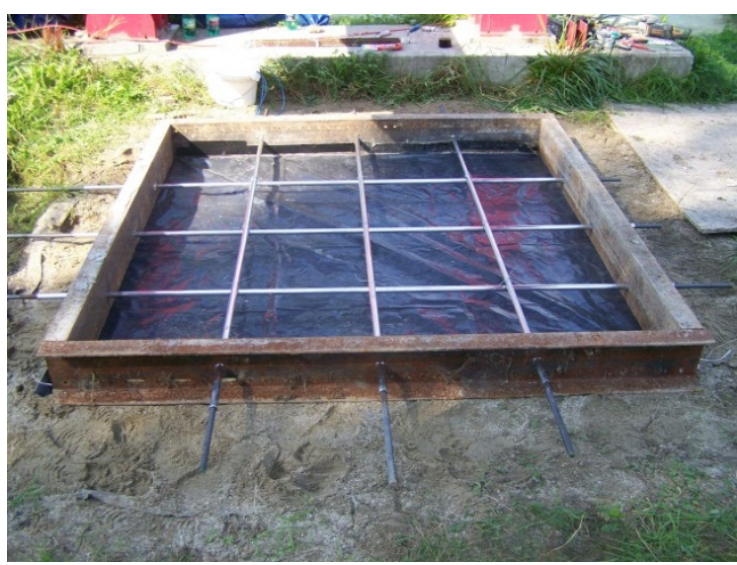

Fig. 2 The steel formwork with ducts for prestressing bars

The materials of threadbars were from low relaxation steel with designation Y 1050 and diameters of these threadbars were $18 \mathrm{~mm}$. The prestress force for each threadbar was $100 \mathrm{kN}$.

The presstresing system with hollow hydraulic cylinder is displayed on Fig. 3.

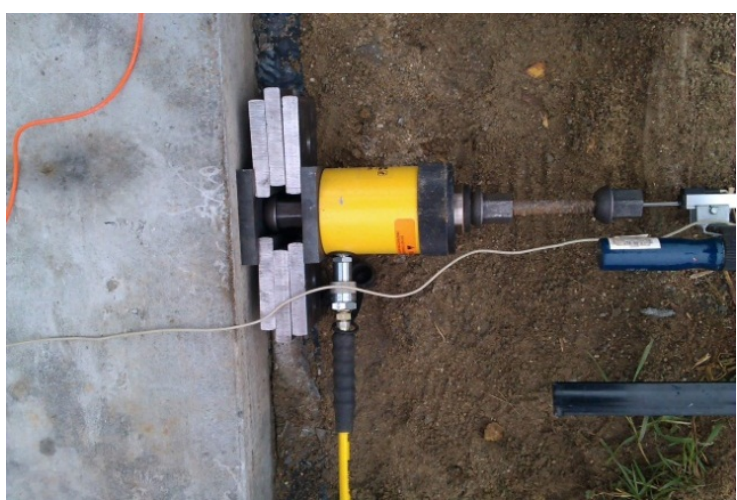

Fig. 3 The presstresing system with hollow hydraulic cylinder

Thredbars were anchored by domed nuts and recessed anchor plates. Positions of threadbars were designed and realized as a centric posttensioning system. The model was laid on homogenous clay subsoil with gravel bed layer. The sliding joint was placed between contact surface of concrete foundation slab model and gravel bed layer. For this experiment was used developed sliding joint construction from parallel research direction at the Faculty of Civil Engineering, VSB - Technical university of Ostrava [13],[14].

\section{DESCRIPTION OF TESTING DEVICES AND MEASUREMENTS}

The outdoor testing device for experimental measurements of foundation slabs on the subsoil "STAND" consists of two frames. Crossbeams enable variability of the press machine location. The frames are anchored with screws into the steel grate based in the reinforced concrete strip foundations. The construction is anchored with 4 $\mathrm{m}$ long micropiles. The highest possible vertical load is $1 \mathrm{MN}$ [17]. The experimental static loading test on a prestressed concrete foundation slab model was the assembly of a set of measurements. Measurement gauges completed the experimental measurement line [7], [8]. Described experiment was short-term static load test without influence of concrete and subsoil creep [18], [19]. Measured data will serve for comparison with results obtained by numerical FEM modeling of soil prestressed foundation slab interaction by [20][23]. The complete assembly for static load test is displayed on Fig. 4.

\section{The experimental measurement line:}

- 3 geotechnical pressure cells for measurement of the stress on the interface of the slab and subsoil. Displayed on Fig. 5.

- Built-in pressure sensor for measurement of the vertical load.

- 4 strain gauges for measurement on the surface of the slab - tension of concrete.

- 4 strain gauges for measurement inside the experimental slab - tension of concrete. Displayed on Fig. 6.

- 14 potentiometric position sensors for measurement of vertical deformations (subsidence). Displayed on Fig. 7.

- 8 temperature sensors for measurement of temperature inside and on the surface.

- Recording station for potentiometric sensors

- Recording station for geotechnical pressure cells

- Leveling device for stiffness control of outdoor testing device "STAND". 


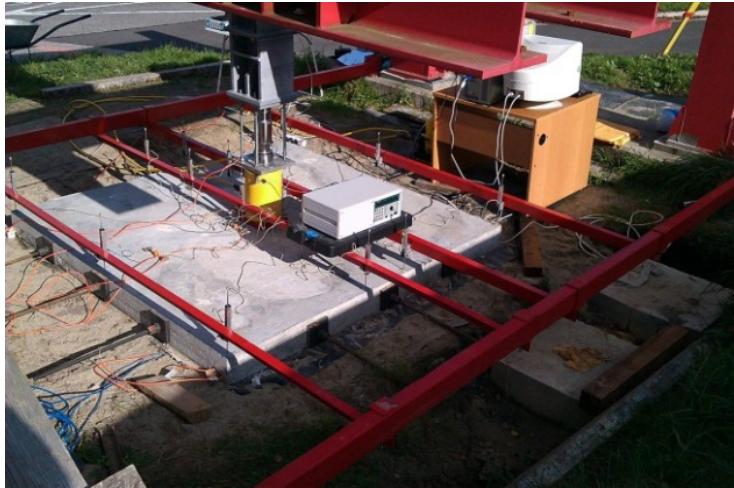

Fig. 4 The presstresing system with hollow hydraulic cylinder

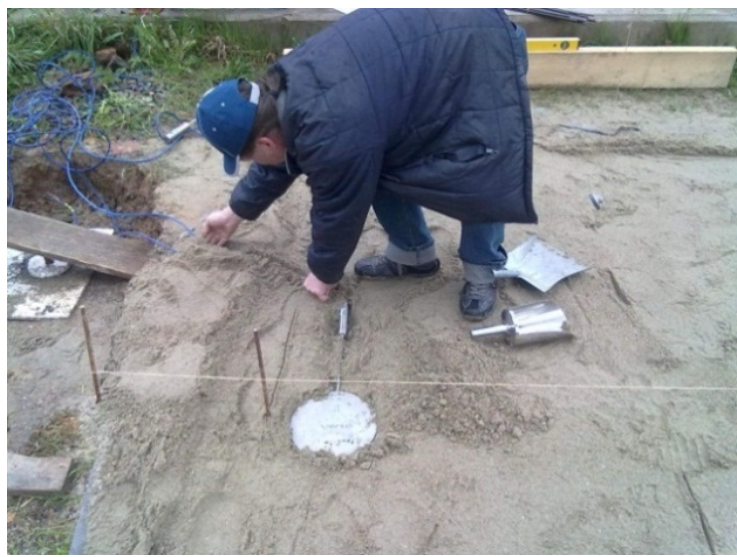

Fig. 5 Installation of geotechnical pressure cells for measurement of the stress on the interface of the slab and subsoil.

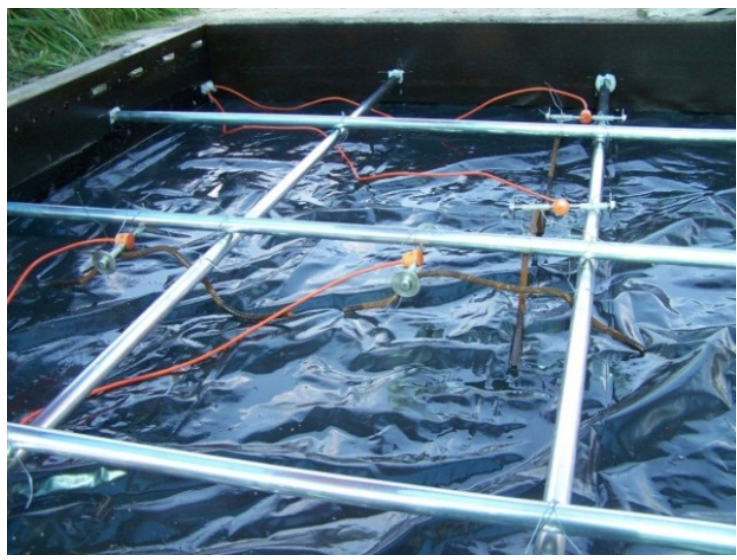

Fig. 6 Strain measurement gauges inside the experimental slab

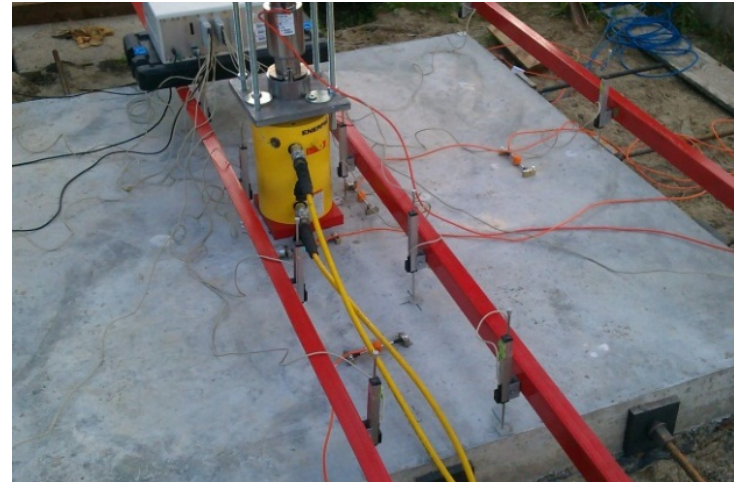

Fig. 7 Potentiometric position sensors for measurement of vertical deformations and built-in pressure sensor for measurement of the vertical load

\section{DESCRIPTION OF EXPERIMENTAL MEASUREMENT PROCESS}

The vertical load was caused by the high tonnage hydraulic cylinder. The loaded equipment was placed between the experimental model and the steel extension fixed on the testing device for experimental measurements of foundation slabs on the subsoil "STAND" The hydraulic system was equipped with the pressure sensor. Potentiometric position sensors were installed on the surface of concrete foundation model. These gauges were connected to the same sensor station with automatic scanning and recording. Shape and size of load area simulated square shape column. Dimensions of load area were 200 x $200 \mathrm{~mm}$. Fixed interval of loading process - $75 \mathrm{kN} / 30 \mathrm{~min}$ was chosen for this experimental testing. After each loading process a 30 minutes long relaxation step continue. Loading process and relaxation step make together one loading step.

\section{MEASUREMENT OF VERTICAL DEFORMATION - SUBSIDENCE}

Vertical deformations were measured by the set of 16 potentiometers. Potentiometers were connected to the recording sensor station. The station was programmed to automatic scanning and recording measured values. Time interval for record of deformation measurement was 10 seconds. Schematic plan of sensors is displayed on Fig. 8. Subsidence results of potentiometric position sensors - deformations at particular points are displayed on Fig.13. 
Measured data were processed to graphs of vertical deformation development - subsidence. The development of subsidence in the edge area of experimental model is represented by crosssections $A-A^{\prime}$ and $C_{-} C^{\prime}$ - displayed on Fig. 9 and Fig. 11. From the graphs of edge area are noticeable the lifting in corners of the experimental model. The development of subsidence in the central area of experimental model is represented by cross-sections B-B' and D-D' - displayed on Fig. 10 and Fig. 12. These graphs displayed centralized subsidence in the central part of experimental model. The creation and progression of punching share is also noticeable from graphs of lines B-B' and D-D'.

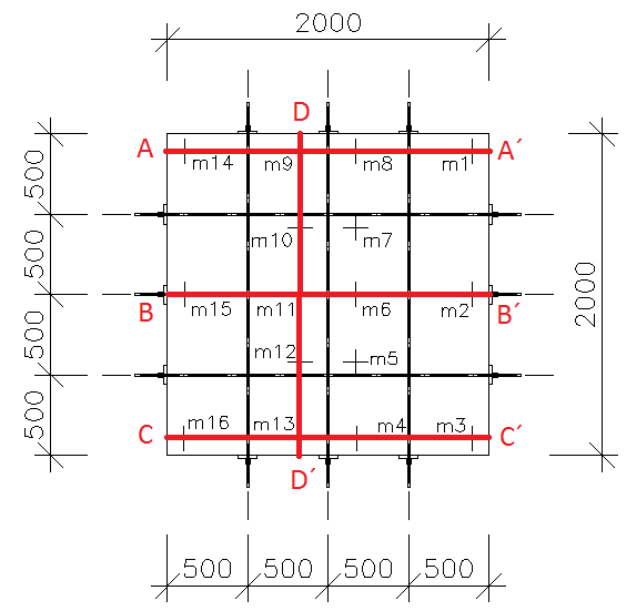

Fig.8 Schematic plan of potentiometric position sensors

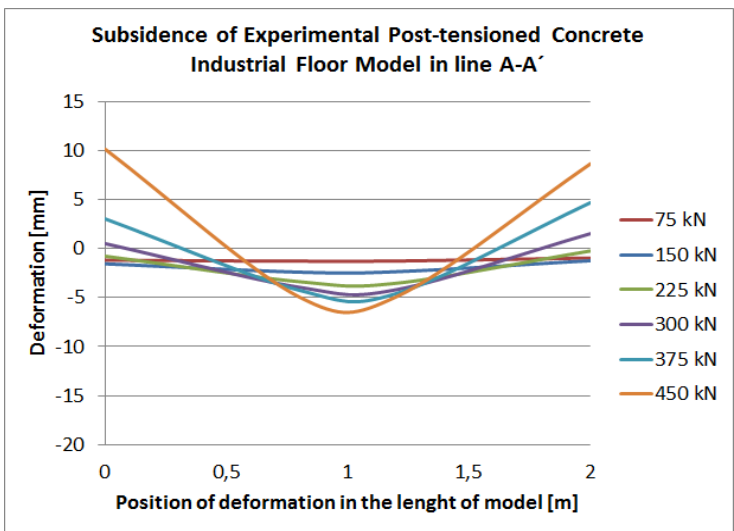

Fig. 9 Subsidence of prestressed concrete foundation model- cross-section A-A' (line A-A' on Fig.8)

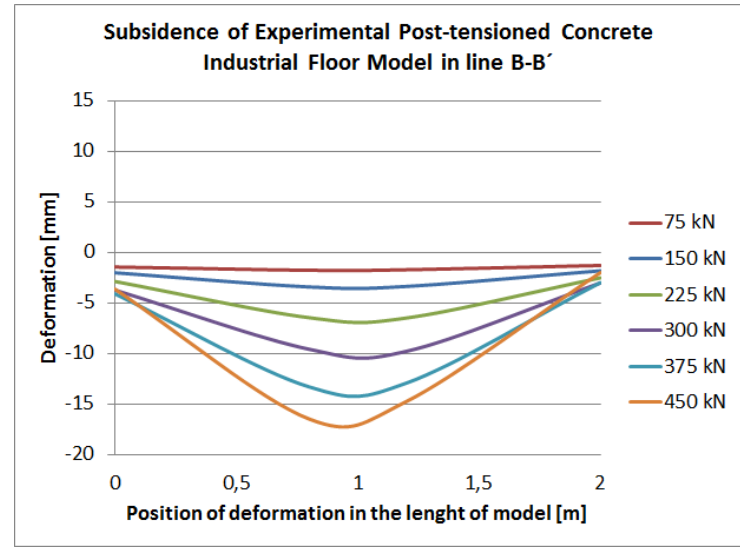

Fig. 10 Subsidence of prestressed concrete foundation model- cross-section B-B' (line B-B' on Fig.8)

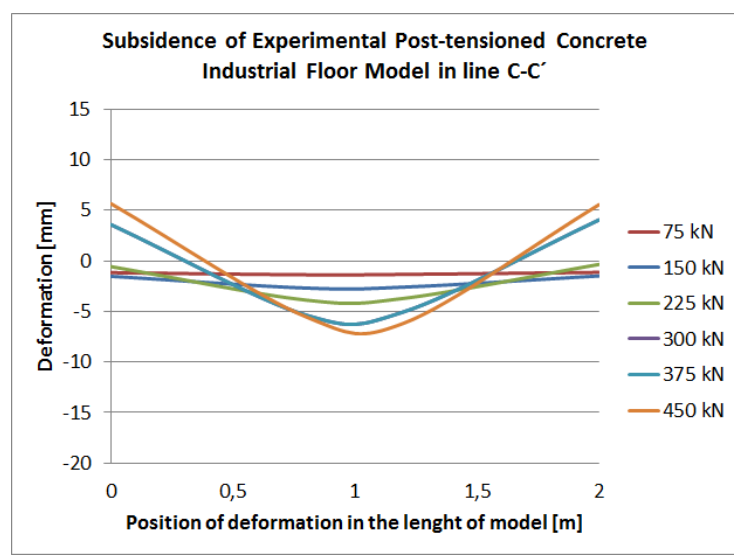

Fig. 11 Subsidence of prestressed concrete foundation model- cross-section C-C' (line C-C' on Fig.8)

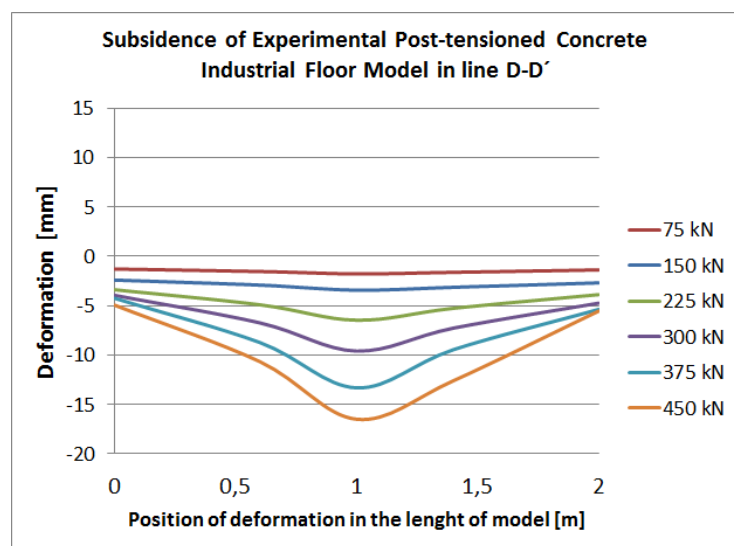

Fig. 12 Subsidence of prestressed concrete foundation model- cross-section D-D' (line D-D' on Fig.8) 


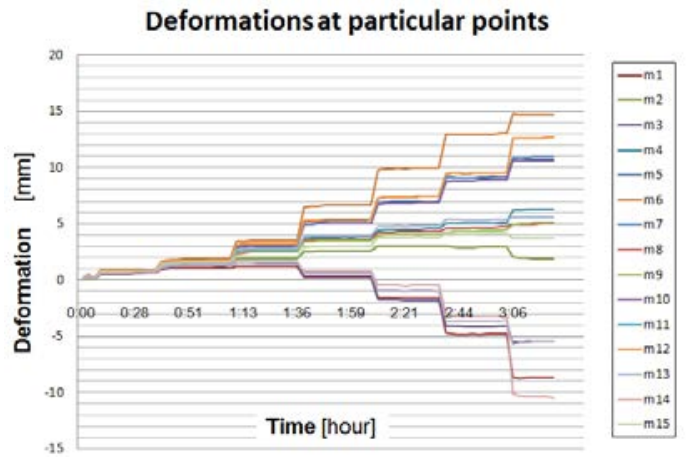

Fig. 13 Results of potentiometric position sensors - deformations at particular points

\section{CONTROL OF COMPRESSIVE STRENGTH CHARACTERISTICS OF TESTED CONCRETE}

Compressive strength characteristics of the tested concrete were verified in according European Standard EN 206:2013. Three pieces of test cubes were taken during the concreting. These cubes, with dimensions 150 × 150 x 150 mm, were allowed to the mature for 28 days. Cube samples were used for the strength characteristic verification in Compressive strength characteristics of the tested concrete were verified in according CSN EN 12390 - 3. Tested concrete was classified as C35/45. Tests of compressive strength characteristics were realized in the laboratory of Faculty of Civil Engineering in Ostrava.

\section{EXPERIMENTAL EVALUATION OF THE POST-TENSIONED CONCRETE SLAB CONTACT SURFACE}

The location of the test pattern inside the testing device for experimental device "STAND" and the use of available handling techniques enabled to lift the test slab.

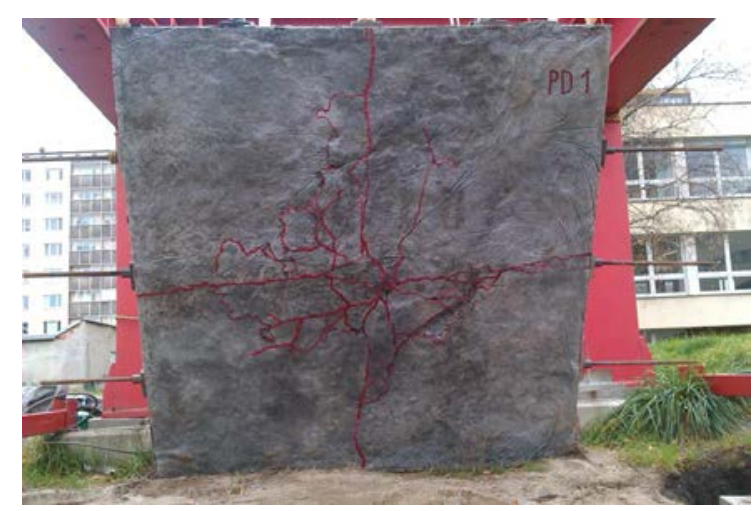

Fig. 14 The course of cracks on the contact surface of experimental post-tensioned slab
Threadbars were used for anchorage for stretching hanging straps. A pair of chain hoists was hung on the "STAND" beams. The experimental pattern was lifted and allowed the course of cracks evaluation right on concrete slab surface that was in contact with the subsoil. The crack cross is highlighted with red color on Fig.14. Punching shear damage are displayed on Fig. 15 and Fig. 16. Next cracks were localized near anchors of middle prestressing threadbars displayed on Fig.17.

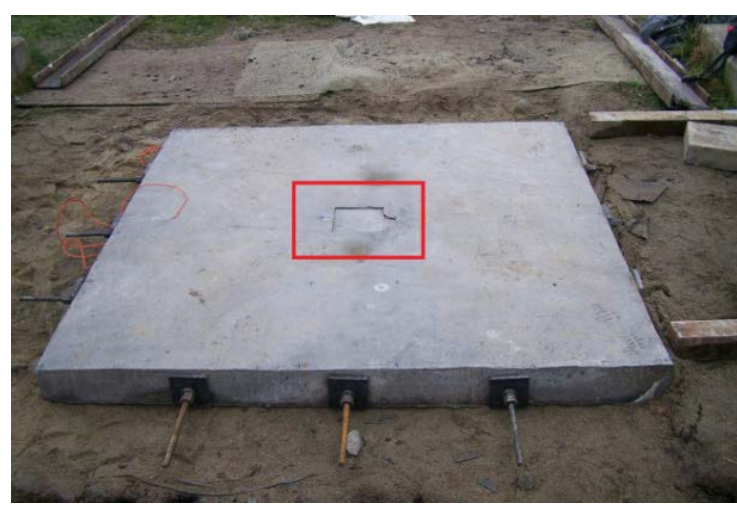

Fig. 15 Punching shear damage on the upper surface of experimental post-tensioned slab

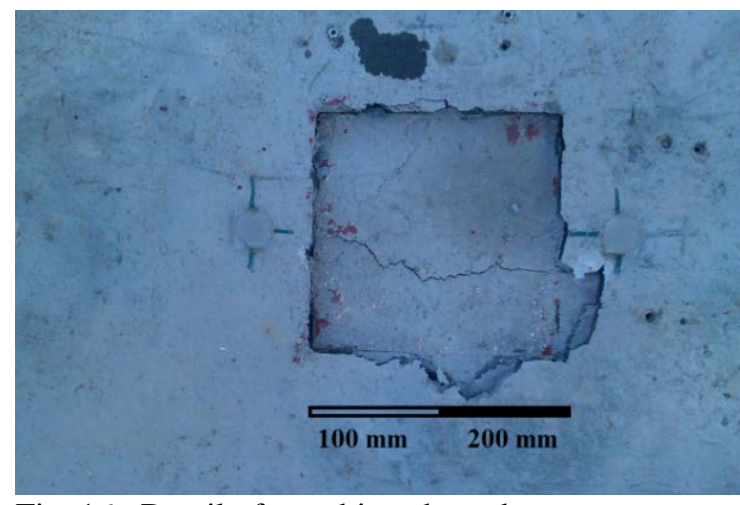

Fig. 16 Detail of punching shear damage

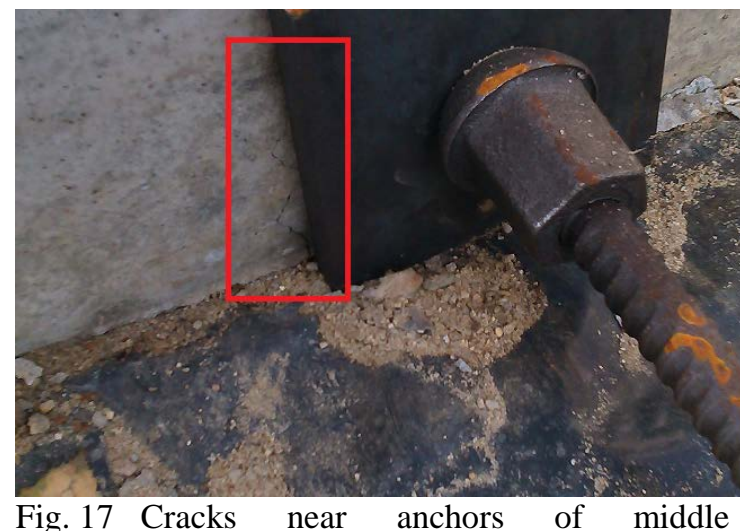

prestressing threadbar 


\section{STAND EXPERIMENTAL DEVICE - STIFFNESS CONTROL}

During the course of the experiment, it was necessary to check the experimental device stiffness.

The test stand was equipped with a leveling target and, the leveling device was targeted at this mark during the test. Thanks to this measure, the beam deflection, to which was connected a hydraulic press, could be continuously controlled. Position of leveling device is displayed on Fig. 18.

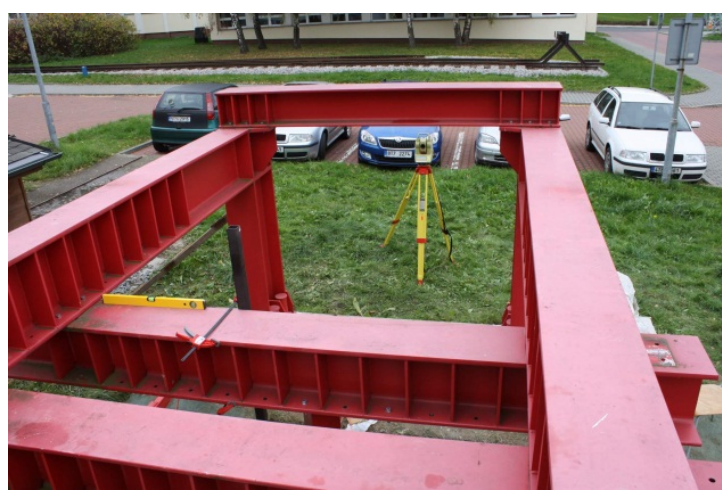

Fig. 18 Position of leveling device

\section{CREATION OF THREE DIMENSIONAL FEM MODEL}

The concrete slab was modelled as a twodimensional structure using a SHELL 181shell element. Uniform thickness was set to $150 \mathrm{~mm}$ for the shell elements. The subsoil was modelled with a SOLID 45 three-dimensional solid element. A regular finite element mesh was generated on both the plate and the subsoil. The dimensions of elements representing the modelled area of subsoil were $0.1 \times 0.1 \times 0.1 \mathrm{~m}$. The area of the plate was meshed using elements with a size of $0.1 \times 0.1 \mathrm{~m}$.

A nonhomogeneous half-space was used for the analysis of the interaction between the loaded prestressed slab and the subsoil. The concentration of vertical stress in the axis of the foundation differs from the homogeneous half-space and the static Young's modulus varies smoothly with depth. This material model can describe the deformation behavior of heterogeneous substances such as soil more accurately.

The contact area between the concrete slab and the subsoil can typically transfer only compressive force and the transfer of compressive force depends on whether the two surfaces are in contact or not. The solution is an iterative process and the calculation automatically includes changing-status nonlinearity. The contact is realized using the contact element pair TARGE170 - CONTA173.
The friction between the concrete slab and the subsoil in the contact area is neglected. The selfweight of the subsoil and the pre-stressed floor slab are also neglected in the calculation.

Vertical load, which was generated by a hydraulic press, was divided into nodes situated in the $200 \times 200 \mathrm{~mm}$ loading area. The load in the point of failure was approximately $525 \mathrm{kN}$. Loading of $100 \mathrm{kN}$ from pre-stressed bars was placed in quarters of all edges of the plate.

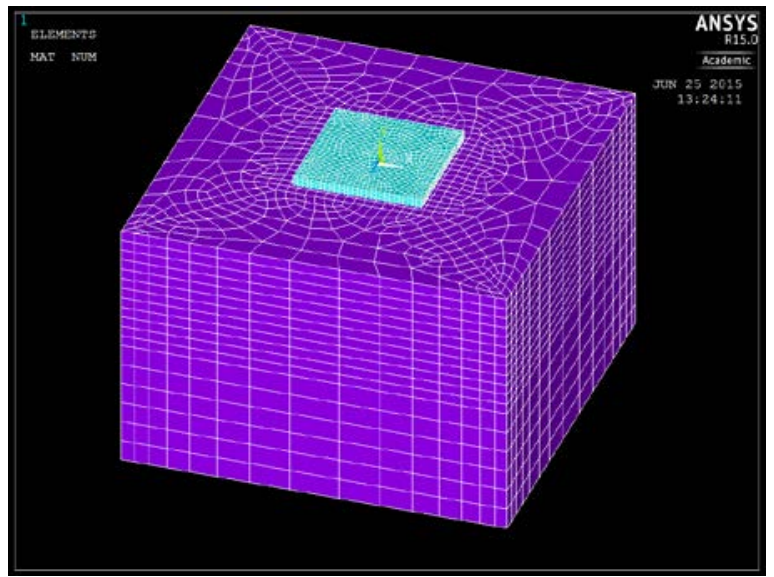

Fig. 19 Regular finite element mesh generated on both the plate and the subsoil

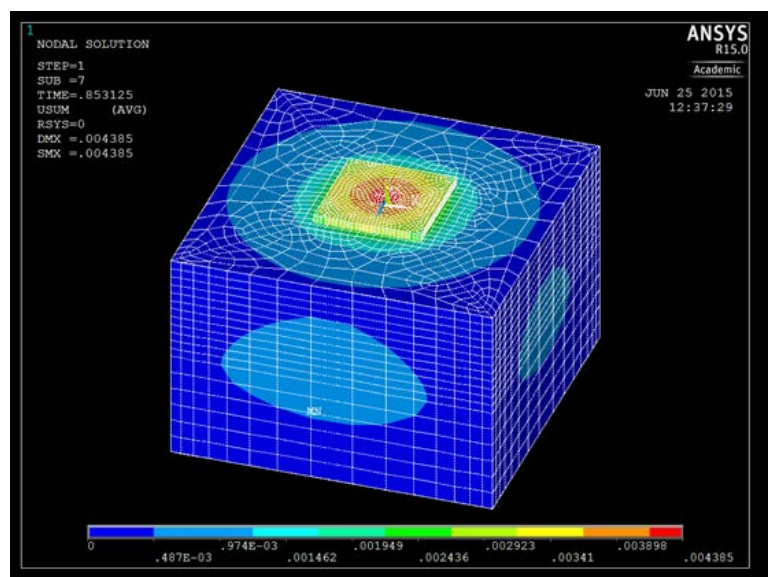

Fig. 20 Distribution of normal stress $\sigma_{\mathrm{z}}$, vertical section through the subsoil model $[\mathrm{Pa}]$

\section{CONCLUSION}

Experimental prestressed concrete foundation slab model resist the loads exerted after seven load cycles and induced maximal load level $525 \mathrm{kN}$. First significant cracks were detected after fourth loading step Cracks were located near anchors of middle threadbars. After sixth loading step were detected first signs of punching shear. Experiment was ended in moment, when the model was strongly damaged by punching shear. Experiment displayed important informations about influence of prestressing to punching shear resistance. 
Measured data will serve for comparison with results obtained by numerical FEM modeling of soil - prestressed foundation slab interaction.

\section{ACKNOWLEDGEMENTS}

This outcome has been achieved with the financial support of the GACR - Czech Science Foundation, project No.16-08937S "State of stress and strain of fiber reinforced composites in interaction with the soil environment“.

\section{REFERENCES}

[1] R. Halvonik, J., Fillo, "The Maximum Punching Shear Resistance of Flat Slabs, Procedia Engineering”, vol.: 65, 2013, pp 376381 , ISSN 1877 - 7058, doi. 10.1016/j.proeng.2013.09.058.

[2] M. Aboutalebi, A. Alani, J. Rizzuto, D. Beckett, "Structural behaviour and deformation patterns in loaded plain concrete ground-supported slabs”. Structural Concrete. 2014, vol. 15, issue. 1, pp. 81-93. ISSN 14644177, DOI 10.1002/suco.201300043.

[3] T. Clément, A.P. Ramos, M.F. Ruiz, A. Muttoni, "Influence of prestressing on the punching strength of post-tensioned slabs", Engineering Structure, vol. 72, pp. 56-69 (14 p), ISSN: 0141-0296, 2014

[4] L. Nguyen-Minh, M. Rovnak, T. Tran-Ngoc, T. Le-Phuoc, "Punching shear resistence of post-tensioned steel fiber reinforced concrete flat plates”, Engineering Structure, vol. 45, pp. 324-337 (14 p), ISSN: 0141-0296, 2012

[5] J. ØVERLI, Experimental and numerical investigation of slabs on ground subjected to concentrated loads, Open Engineering, vol. 4(3), DOI: 10.2478/s13531-013-0159-9. ISSN 23915439. 2014.

[6] A. Meda, G.A. Plizzari, New design approach for steel fiber-reinforced concrete slabs-onground based on fracture mechanics, ACI Structural Journal, vol. 101 (3), pp. 298-303, 2004.

[7] P. Mynarcik, "The Subsidence Analysis of Experimental Post-tensioned Concrete Slab Model in the Course of the Static Load Test”, Applied Mechanics and Materials, vol. 744 746, pp. 1556-1559 (4 p), Trans Tech Publications, Switzerland, doi:10.4028/www.scientific.net/AMM.744746.1556, 2015.

[8] P. Mynarcik, "Measurement processes and destructive testing of fibre concrete foundation slab pattern”, Advanced Material Research, vol. 1020, pp. 221-226 (6 p), Trans Tech Publications, Switzerland, ISSN (Online) 1662-8985, ISSN (Print) 1022-6680,
DOI: 10.4028/www.scientific.net/AMR.1020. 221, 2014.

[9] P. Mynarcik,. "Core Sampling for Fiber Concrete Constructions - Context Between Quantity of Core Samples and Evaluation of Fiber Concrete Characteristics" Procedia Engineering [online]. 2015, 114: 493-499. DOI: 10.1016/j.proeng.2015.08.097.

[10]R. Cajka, K. Burkovic, V. Buchta, "Foundation Slab in Interaction with Subsoil", Advanced Materials Research, Volumes 838841, pp. $375-380$ (6 p), Trans Tech Publications, Switzerland, doi:10.4028/www.scientific.net/AMR.838841.375, 2014.

[11]R. Cajka, P. Manasek, "Building Structures in Danger of Flooding”. IABSE Conference New Delhi, India 2005: Role of Structural Engineers towards Reduction of Poverty. New Delhi, India, pp. 551-558 ISBN 978-3-85748111-6, WOS: 000245746100072, 2005.

[12]R. Cajka, P. Mateckova, "Comparison of calculating methods and consequent carrying capacities of pre-stressed precast concrete roof purlin”, in proceedings of First International Workshop "Design of Concrete Structures using EN 1992-1-1, Prague, 15 March 2010, ISBN 978-80-01-04581-7, WOS: 000324078100017, 2010

[13] M. Janulikova, R. Cajka, P. Mateckova, V. Buchta, "Laboratory Testing of Asphalt Belts Rheological Properties Exposed to Shear Loads”, Transactions of the VŠB - Technical University of Ostrava, Civil Engineering Series, vol. XII, iss. 2, pp. 59-66 (8 p), ISSN (Online) 1804-4824, ISSN (Print) 1213-1962, doi: 10.2478/v10160-012-0018-2, 2013.

[14] M. Janulikova, M. Stara, "Multi-layer Rheological Sliding Joint in the Foundation Structures”, Transactions of the VŠB Technical University of Ostrava, Civil Engineering Series, vol. XIII, iss. 2, pp. 41-46 (6 p), ISSN (Online) 1804-4824, ISSN (Print) 1213-1962, doi: 10.2478/tvsb-2013-0008, 2013.

[15] M. Janulikova, P. Mynarcik, "Modern Sliding Joints in Foundations of Concrete and Masonry Structures”, International Journal of Mechanics, vol.8, iss.1, United States: North Atlantic University Union, pp. 184 -189 (6 p), ISSN 1998-4448, 2014.

[16] M. Janulikova, M. Stara, P. Mynarcik, "Sliding Joint from Traditional Asphalt Belts", Advanced Material Research, vol. 1020, pp. 335-340 (6 p), Trans Tech Publications, Switzerland, ISSN (Online) 1662-8985, ISSN (Print) 1022-6680, doi: 10.4028/www.scientific.net/AMR.1020.3 35, 2014. 
[17] R. Cajka, V. Krivy, D. Sekanina, “Design and Development of a Testing Device for Experimental Measurements of Foundation Slabs on the Subsoil", Transactions of the VŠB - Technical University of Ostrava, Civil Engineering Series, vol. XI, iss. 1, pp. 1-6 (6 p), ISSN (Online)1804-4824, ISBN 978-80248-2332-4, doi: 10.2478/v10160-011-0002-2, 2011.

[18] J. Navratil, "Structural analysis of bridges, legitimate conservatism and obsolete theories", Concrete Engineering International, vol.:8 (1), pp. 17-19, ISSN 14605856, 2004.

[19] J. Navratil, M. Zich, "Long-term deflections of cantilever segmental bridges”, Baltic Journal of Road and Bridge Engineering, vol.: 8, issue 3, pp 190-195. ISSN: 1822427X, DOI: 10.3846/bjrbe.2013.24, 2013.

[20]R. Cajka, “Analytical derivation of friction parameters for FEM calculation of the state of stress in foundation structures on undermined territories”, Acta Montanistica Slovaca, vol. 18, iss. 4, pp. 254-261 (8 p), ISSN: 13351788, 2013.

[21] M. Janulikova, M. Stara, "Reducing the Shear Stress in the Footing Bottom of Concrete and Masonry Structures”, Procedia Engineering, vol. 65, pp. 284 - 289 (4 p), ISSN 1877-7058, DOI:10.1016/j.proeng.2013.09.044, 2013.

[22] J. Labudkova, R. Cajka, "Comparsion of Measured Displacement of the Plate in Interaction with the Subsoil and the Results of 3D Numerical Model”, Advanced Material Research, vol. 1020, pp. 204-209 (6 p), Trans
Tech Publications, Switzerland, ISSN (Online) 1662-8985, ISSN (Print) 1022-6680, DOI: 10.4028/www.scientific.net/AMR.1020. 204, 2014.

[23] J. Labudkova, R. Cajka, "Comparison of the Results from Analysis of Nonlinear Homogeneous and Nonlinear Inhomogeneous Half-Space" Procedia Engineering [online]. 2015, 114: 522-529. DOI: 10.1016/j.proeng.2015.08.10

[24] Tomita Y., Nishigata T., Masui T., Yao S. "Load settlement relationships of circular footings considering dilatancy characteristics of sand”, International Journal of GEOMATE, 2 (1), pp. 148-153., 2012.

[25]Benadla Z., Hamdaoui K., Aissaoui S., Baouch A.”Influence of the soil-structure interaction on the seismic behavior of buildings on shallow foundations", International Journal of GEOMATE, 6 (1), pp. 811-816, 2014.

International Journal of GEOMATE, June, 2016, Vol. 10, Issue 22, pp. 2101-2108.

MS No. 5385 received on June 30, 2015 and reviewed under GEOMATE publication policies.

Copyright (C) 2015, Int. J. of GEOMATE. All rights reserved, including the making of copies unless permission is obtained from the copyright proprietors. Pertinent discussion including authors' closure, if any, will be published in Feb. 2017 if the discussion is received by Aug. 2016.

Corresponding Author: Radim Cajka 